\title{
ДИСТАНЦІЙНЕ НАВЧАННЯ: РЕАЛІЇ І ПЕРСПЕКТИВИ
}

\author{
https://doi.org/10.37472/2707-305X-2020-2-1-10-1
}

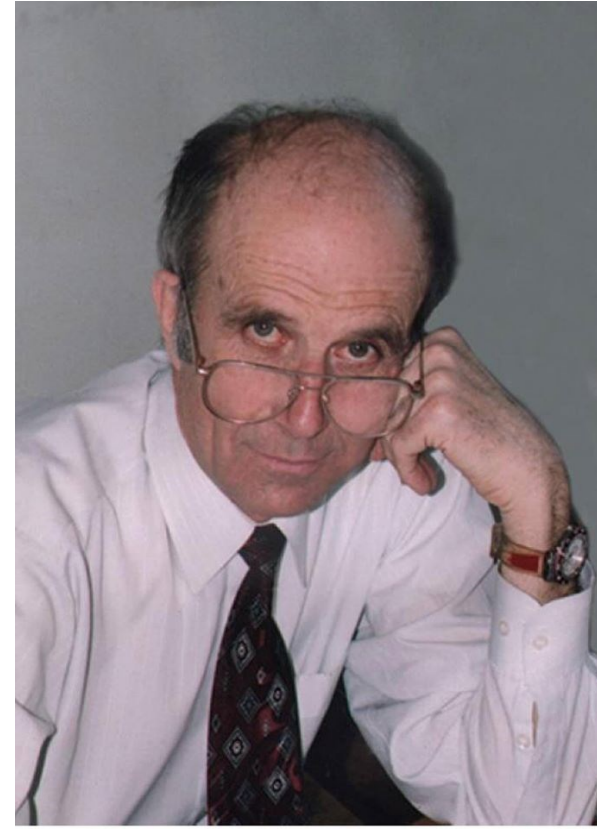

МАЛЬОВАНИЙ Юрій Іванович кандидат педагогічних наук, старший науковий співробітник, член-кореспондент НАПН України, вчений секретар Відділення загальної середньої освіти Національної академії педагогічних наук України, м. Київ, Україна

(1) $\theta$
Анотація. У статmі на підставі даних, здобутих у процесі оперативних досліджень учених Відділення загальної середньої освіти НАПН України, виокремлено основні проблеми в організації $i$ здійсненні навчання учнів закладів загальної середньої освіти в онлайн-режимі під час масового короновірусного карантину. Серед них - відсутність якісного інтернет зв'язку, неповне забезпечення суб'єктів освітнього процесу необхідними гаджетами для його ефрективного здійснення, відсутність належного попереднього досвіду роботи в умовах дистанційного навчання, недостатня методична підготовленість педагогів до такого виду навчання та ін. Окреслено пріоритетні напрями удосконалення й розвитку дистанційного навчання. Висловлено застереження щодо абсолютизації можливостей дистанційного навчання і перспективи утвердження його як єдиного панівного виду навчання в освітньому просторі країни.

Ключові слова: дистанційне навчання онлайн; проблеми організації дистанційного навчання; пріоритетні напрями розвитку дистанційного навчання.

Короновірусне випробування країни на життєстійкість, раціональність організації та ефективність функціонування державних структур, соціальних інституцій і цілих галузей актуалізувало низку проблем. Необхідність розв'язання частини з них якщо й усвідомлювалася раніше, то через різні обставини здійснювалась мляво, без належного розуміння їх впливу на успішність подальшого поступу нації у ії цивілізаційному розвитку. Не стала винятком у цьому контексті й освітня галузь, зокрема той ії істотний сегмент, що забезпечує реалізацію права громадян на здобуття повної загальної середньої освіти. Тож першочергове завдання сьогодні - виокремити й проаналізувати ті найважливіші виклики, які постали перед галуззю в умовах карантину, й окреслити варіанти ефективного на них реагування.

Ученими Відділення загальної середньої освіти Національної академії педагогічних наук України, а саме Інституту педагогіки (Бурда \& Васильєва, 2020), Інституту інформаційних технологій і засобів навчання (Овчарук \& Іванюк, 2020а; Овчарук \& Іванюк, 2020b) та Інституту обдарованої дитини (2020) НАПН України, оперативно здійснено низку досліджень, які передбачали з'ясування ступеня готовності закладів освіти і педагогів здійснювати навчання за відсутності безпосереднього контакту вчителя з учнями та учнів між собою, визначення технічних, організаційних, методичних труднощів, які яскраво проявилися під час дистанційного навчання, його сильних сторін та недоліків, а також окреслення шляхів подальшого розвитку. Хоча 3 деяких причин ці дослідження не можна вважати достатньо репрезентативними, все-таки їх результати можуть слугувати 
вірогідною основою для таких найістотніших узагальнень і висновків.

Одним із істотних чинників, який негативно вплинув на можливість успішно організувати і повсюдно здійснити дистанційне навчання онлайн, виявилася відсутність якісного інтернетзв'язку. На цей фактор вказала більш ніж половина усього загалу вчителів і учнів з різних регіонів України, які долучилися до дослідження (а таких налічувалося близько 2 тис. осіб). Ці дані суголосні з офіційними даними Міністерства цифрової трансформації України (2020), згідно з якими лише 60 \% шкіл нашої країни під'єднані до Інтернету за допомогою оптоволоконних технологій. Решта шкіл такого під'єднання не має.

Ще один істотний негативний фактор із технічної категорії - це недостатнє забезпечення учасників освітнього процесу необхідною повноцінною комп'ютерною технікою (близько $60 \%$ респондентів охарактеризували таке забезпечення як часткове, а понад 10 \% - як повністю відсутнє).

Суттєві труднощі у здійсненні дистанційного навчання зумовлені недостатнім попереднім досвідом педагогів у його проведенні та відсутністю належної методичної підготовки для організації. Учителям бракувало інформованості про освітні онлайн-ресурси, які можна було використовувати у такій ситуації, а також умінь добирати й ефективно застосовувати відповідні технології навчання. Значні труднощі були пов'язані із забезпеченням оперативного педагогічного управління навчальною діяльністю учнів, здійсненням контролю й оцінювання результатів цієї діяльності в змістовому, організаційному і технологічному аспектах. Не сприяв ефективності дистанційного навчання і недостатній рівень інформаційно-комунікаційної компетентності деяких педагогів і учнів (за їх власним визнанням).

Усі зазначені та інші фактори спричинили серйозне перевантаження учасників освітнього процесу в онлайн-режимі. Учителі відзначали, зокрема, значне збільшення затрат часу для підготовки до занять, учні скаржилися на перевантаженість різними видами робіт, які їм доводилося виконувати без належного володіння необхідними уміннями самостійної навчальної діяльності.

Про результативність дистанційного навчання, зумовленого карантином, говорити ще рано. А от найважливіші напрями удосконалення та розвитку цього виду навчання уже окреслюються.
Одним із них $є$ забезпечення усіх учасників освітнього процесу надійним інтернет-зв'язком і необхідними цифровими засобами спілкування для ефективної роботи в режимі онлайн.

Другий важливий напрям - створення якісного, всеосяжного, вседоступного базового контенту, який давав би можливість педагогам не лише використовувати готові технології, а й вибудовувати власні онлайн-системи навчання предмета.

Третій напрям - здійснення підготовки кожного вчителя - і нинішнього, і майбутнього - до ефективної роботи в умовах дистанційного навчання, забезпечення сформованості необхідних для цього методичної, інформаційнотехнологічної та інших компетентностей. Відповідну підготовку слід забезпечити і для учнів.

Четвертий напрям стосується надійного науково-методичного супроводу дистанційного навчання, розроблення його цілісної дидактичної теорії і дослідження методичних аспектів.

П’ятий напрям - упорядкування на державному рівні нормативного регулювання дистанційного навчання.

I насамкінець - важливе запитання, яке поки що залишається відкритим: «Яким $є$ майбутнє дистанційного навчання?» Чи стане воно панівним у всьому освітньому просторі, поступово витіснивши і замінивши все, що ми мали до цього часу? Адже вже зараз доводиться чути непоодинокі прогнози, які малюють майбутнє освіти без школи і вчителя, а лише з учнем, який сидить за комп'ютером і навчається й розвивається самостійно, використовуючи надможливості цифрового освітнього простору для конструювання і реалізації власної освітньої траєкторії. Чи не поспішними є подібні прогнози? Адже досі ми не маємо достатніх і однозначних результатів психолого-педагогічних, фізіологічних та інших досліджень щодо особливостей такого навчання, його можливостей і впливу на розвиток різних сфер особистості учня, що мало б бути підставою для виважених висновків. Інтенсифікувати, поглибити і розширити такі дослідження невідкладно мають відповідні наукові структури і окремі фахівці. Поки що ж слід зауважити, що більшість учасників дослідження - і учнів, і вчителів - одностайно вказала на гострий дефіцит безпосереднього, живого спілкування, який вони відчували в процесі дистанційного навчання, що спричиняло В них принаймні психологічний дискомфорт. 
Узагалі не можна недооцінювати потенціал могутнього впливу на формування особистості в моральному, духовному, соціальному аспектах прямих контактів, безпосереднього постійного спілкування, живої взаємодії учасників освітнього процесу, що притаманне лише традиційному, т. зв. очному навчанню. Саме у процесі спілкування, тим паче спеціально організованого і відповідно спрямованого, відбувається усвідомлення знань, проникнення в їх сутність, формується здатність слухати й чути, формулювати, обґрунтовувати і відстоювати власну думку, розвивається критичне мислення. Не слід ігнорувати й аспект морального, духовного впливу особистості педагога на особистість учня у процесі їхнього спілкування. "Духовними зустрічами з учителем» називалися можливості подібного спілкування ще у древньокитайській педагогіці. Це - спілкування на рівні почуттів, що передбачало повний душевний контакт між наставником і учнем і справляло неоціненний облагороджувальний вплив на особистість останнього та цінувалося вище від усього. Ніякі штучно створені високотехнологічні «мертві» новітні освітні середовища такого забезпечити не спроможні.

\section{СПИСОК ВИКОРИСТАНИХ ДЖЕРЕЛ}

Бурда, М.І., \& Васильєва, Д.В. (2020). Уроки довготривалого карантину. Математика в рідній школі, (3), 30-33.

Інститут обдарованої дитини НАПН України. (2020). Результати опитування "Виклики дистанційного навчання». http://iod.gov.ua/news.php?readmore=427

Міністерство та Комітет цифрової трансформації України. (2020, 4 червня). 40 \% українських шкіл не мають якісного підключення до інтернету. https://thedigital.gov.ua/news/40-ukrainskikh-shkilne-mayut-yakisnogo-pidklyuchennya-do-internetu

Овчарук, О.В., \& Іванюк, І.В. (2020а). Результати онлайн опитування "Потреби вчителів у підвищенні фахового рівня з питань використання цифрових засобів та IKT в умовах карантину»: аналітичні матеріали. Київ: ІІТЗН НАПН України. https://lib.iitta.gov.ua/719908/

Овчарук, О.В., \& Іванюк, І.В. (2020b). Результати онлайн-опитування «Потреби вчителів у підвищенні фахового рівня з питань використання цифрових засобів та IKT в умовах карантину». Вісник Начіональної академії педагогічних наук України, 2(1). https://doi.org/10.37472/2707-305X-2020-2-1-7-1

\section{DISTANCE LEARNING: REALITIES AND PROSPECTS}

Yurii Malovanyi

PhD in Pedagogy, Senior Researcher, Corresponding Member of NAES of Ukraine, Scientific Secretary of the Division of General Secondary Education, National Academy of Educational Sciences of Ukraine, Kyiv, Ukraine

Abstract. The main problems in organising and conducting the distance online learning of general secondary education institutions' students during the mass coronavirus quarantine are singled out based on the data received from operational researches of the Division of General Secondary Education of NAES of Ukraine institutions. Among them are lack of quality internet connection; incomplete provision of the educational process individuals with the necessary gadgets for its effective implementation; lack of proper previous experience in distance learning; insufficient methodological readiness of teachers for this mode of learning, etc. The priority directions for distance learning improvement and development are enlightened. The reservations on the absolutization of distance learning opportunities and the prospects of its establishment as the only dominant mode of learning in the Ukrainian education area are expressed.

Keywords: distance online learning; problems of distance learning organization; priority directions of distance learning development. 